\title{
Corporate purpose and personhood: an introduction
}

Corporate purpose and personhood have a long lineage in corporate law as distinct and important elements in defining the place of corporate entities in business and the larger society. Yet neither has aged well and in modern times each has shrunk to a shadow of its former role. Purpose arose as a tool to delineate and limit the reach of corporate entities, dating back to the time when the sovereign jealously guarded corporate powers and privileges. It remains a requirement for the modern corporation's organization but became practically invisible in a changed regulatory regime where all U.S. states embraced general incorporation statutes that allow corporations to engage in any lawful business. Corporate personhood and its well-trodden theories based on the entity as a concession from the state, an aggregate of individuals, or a real entity generated seemingly endless debates across the early decades of the 20th century that John Dewey seemingly buried by the end of the 1920s, leaving further development to limp along through most of the last century.

In today's corporate world these two concepts have been repurposed in the service of better describing the modern corporation, now more powerful than ever before, and capable of capturing the international dimension of this discussion in an increasingly digital space. Purpose has become the frontline of a wide-ranging debate over shareholder vs. stakeholder primacy and profit maximization vs. broader social purposes. New entity forms such as benefit corporations have been invented to facilitate this broader purpose. Corporations and investors are under pressure to include ESG (environmental, social, and governance) factors in their decision-making and disclosures. The reset has accelerated even as these chapters have been in preparation. The Business Roundtable, a group of the CEOs of some of the country's largest corporations, released a restatement of their long-standing views of corporate purpose in 2019 to take in the broader range of ideas that are at the center of this book. The response to the Black Lives Matter movement across 2020 and the widening involvement of corporations in that discussion further evidenced the scope of the new paradigm.

At the same time, there has also been new attention to the rights of corporations and their influence in a democratic society. The Supreme Court's decisions in Citizens United and Hobby Lobby and its broad recognition of constitutional rights for corporations beyond those previously recognized have dramatically raised the profile of the discussion about corporate personhood. The recurring attention to corporate claims as to freedom of speech and free exercise of religion in cases since those two decisions has meant that the high court is paying more attention to corporate law issues now than it has over the last half-century or more, while the issues generate a plethora of views that mostly escape easy resolution. This book's intentional linking of purpose and personhood reflects the overlapping ways in which these two somewhat dusty relics of an earlier time look very different when viewed through a modern lens, and sheds light on the modern corporation in ways that would not have seemed possible earlier.

We have divided the twenty contributions to this volume among a handful of parts. The opening part provides an overview with chapters that frame the debate by reviewing first the economic and then the legal lay of the land in which this new debate has begun to unfold. The third piece in this part provides an example of how a 21 st-century lens for viewing corporate purpose and personhood will leave us with a different picture and a new understanding of 
these topics. The focus of Part II is the shareholder vs. stakeholder debate that is perhaps the most visible dichotomy that continues to appear in corporate law writing about this topic. The related topics of benefit corporations and ESG appear in this set of contributions raising similar issues. Part III broadens the subject of the discussion to take in a variety of different theoretical explanations that our authors have adopted to frame the legal discussion from logic and macroeconomics to the classic work of John Dewey or metaphysics, morality, and social perception. In Part IV, the topic of the chapters shifts to a focus on corporate personhood and how to define the rights of corporations. The chapters in Part V illustrate what may be gained by including a comparative or international perspective.

The remainder of this introduction reflects the editors' take on this wonderful set of contributions. We hope that it may inspire you to dig deeper into this material. We know that you will find many additional ideas beyond those we have highlighted here that will further stimulate your thinking.

\section{JUMPING OFF POINTS FOR A NEW LOOK AT TRADITIONAL TOPICS}

The current issues swirling around corporate purpose and personhood did not arrive fully formed and are still developing as all of the chapters in this book illustrate. We begin with three chapters that offer the reader an entrée into foundational debates and challenges.

Brian Cheffins, who is known for his ability to bring together themes that play out over lengthy periods, takes on one of the key economic foundations that has framed economic understanding of the corporate form over the last four decades. His specific focus is Jensen and Meckling's 1976 article 'Theory of the Firm' that is often cited as a key inspiration in moving shareholder value maximization to the center of the debate over corporate purpose. Cheffins canvasses the large gap between what the two financial economists supposedly said about the public company and its governance and what they actually said. His explanation for how this discrepancy occurred provides a helpful foundation for considering the stakeholdershareholder debate that is to follow in subsequent chapters.

To complement this economic focus, Ed Rock explores "What's law got to do with it." In particular, he examines early empirical results finding correlations between firm performance and businesses organized around a defined purpose that reaches beyond profit maximization, suggesting that purpose-driven businesses may outperform their competition. Rock then explores the corollary legal question of which organizational form is best suited for such purpose-driven business. Using a typology from a framework used to introduce business entities in a typical law school class and a parallel discussion of whose interests count in the legal form (e.g., Delaware law), Rock works through three types of firms: traditional "shareholder primacy" firms; purpose-clarity firms; and social enterprise firms. Rock concludes it is essential to distinguish between "business purpose" and "corporate objective" to decide what sort of organizational form is best suited for a particular enterprise. In a world of heterogeneous business purposes and investors with varied preferences, Rock touts the extensive menu of enterprise forms with different corporate objectives as a great virtue of the law. Purpose-driven business might fit a traditional corporate form in some circumstances, but the benefit corporation form may provide a better structure for specifying and monitoring credible, long-term commitments to non-shareholder interests. 
The third chapter in this segment, by Veronica Root Martinez, calls for a rethinking of traditional notions of corporate purpose in light of the historical context in which those ideas arose. She observes ways in which the traditional legal frames, such as the Berle and Dodd debate of the early 1930s, used seemingly neutral terms but reflected discriminatory practices of the time that excluded women and people of color. She injects two crucial points to understand the core debate about shareholders and stakeholders. First, despite the changing demographics of stock ownership, shareholder primacy has failed to broaden conversations about corporate purpose because boards and managers have continued to face barriers to meaningfully considering a diverse set of shareholders' views. Second, historical arguments about the importance of stakeholders were not rooted in achieving racial and gender equality, and the exclusion of certain demographic groups continues to persist among stakeholders today. She concludes by exploring corporate responses to the \#MeToo and \#BlackLivesMatter movements to illustrate how the status quo may be changing, and she suggests future paths for corporate leaders and scholars to reimagine a more equitable corporate purpose.

\section{SHAREHOLDERS VS. STAKEHOLDERS, BENEFIT CORPORATIONS, AND ESG}

Part II includes a series of chapters at the heart of what has been the most visible setting to explore purpose and personhood in the contemporary legal literature. Shareholder primacy has been at the core of corporate governance discussions over the last three decades, now facing a vigorous challenge from those pushing for a more prominent embrace of stakeholder interests. Benefit corporations have been a recurring instrument for suggested change and ESG seen as an alternative approach by which such a change might be implemented.

Jill Fisch and Steven Davidoff Solomon analyze the benefit corporation in a publicly-traded setting. They find that the structure of the benefit corporation does not differ significantly from the traditional corporation in locating control and direction with shareholders - other than requiring a designated social purpose. As to that element they find that the purpose statements in the charters of the most economically significant benefit corporations are, in most cases, too vague and aspirational to be legally significant, or to serve as a reliable check on entity behavior. They conclude that publicly-traded benefit corporations are likely to operate no differently than traditional, publicly-traded corporations absent more defined and enforceable purpose statements.

Perhaps the most recurring argument for shareholder primacy has been its claim as a simple system able to address a possible accountability vacuum in relation to managers. As the movement away from shareholder primacy has gained strength, Dorothy Lund explores how a shift to enlightened shareholder power shifts the traditional analysis. In one sense this complicates shareholder primacy's best defense, just described, but Lund suggests ways that accountability mechanisms can be refashioned. She discusses developments underway to take stakeholder interests into account in setting executive compensation and to evaluate executive and corporate performance using nonfinancial ESG metrics and standards for disclosure. Such "new thinking" as to the accountability vacuum could move the needle closer than ever to an accountable and enlightened governance system.

In a time when the prevailing movement often seems to be a shift from shareholder primacy and a focus on profit maximization to a broader social purpose for corporations, Lisa Fairfax 
notes that the idea of shareholder power has been seen as antithetical to the movement. Her chapter flips that worry, developing the upside of increased shareholder power. While acknowledging the threat posed by shareholder power, she bases her counterargument on how shareholders have used their increased power to request, and in some cases demand, that corporations embrace social purpose and commit to advancing the concerns of all stakeholders. In a world where institutional shareholders are ubiquitous, some of the most influential shareholders are using their power and influence to meaningfully advance stakeholder interests. She concludes that the widespread embrace of a corporate social purpose would not exist without this increased shareholder power.

Ann Lipton follows something of a parallel track in leaning in to shareholder power rather than resisting it. Her focus is on ESG-the diverse range of possible motivations for its use and its limitations. What does it take for such a middle ground approach to succeed when it relies on shareholders to prod corporations to act in ways that protect non-shareholder constituencies? The answers suggested here are not entirely optimistic, as both legal and practical barriers abound. Lipton concludes by situating the potential success of the ESG movement within a broader and more transparent legal structure that is symbiotic with an empowered non-shareholder constituency backed up by strong regulatory presence.

Benefit corporations and ESG, of course, don't exhaust the business forms and strategies in which broader commitments to a social mission might be pursued. Brett McDonnell adds three more-low-profit LLCs (L3Cs), nonprofits, and cooperatives - in a cohort in which he also considers benefit corporations. In these alternative examples he sees how different legal rules may help businesses behave in ways other than the traditional profit maximization mode. This focus on how different legal forms of business association can be matched to the "on the ground" contexts to achieve a stronger commitment to desired social control parallels Ed Rock's structural examination of an earlier chapter.

Cynthia Williams reminds us that these themes are not entirely new. Although in many ways the takeover era of the 1980s reflects the apogee of shareholder wealth maximization, Williams reframes examples from this period with insights from stakeholder-oriented thinkers such as Marty Lipton, Lynn Stout, and Colin Mayer, to argue for a new vision of corporate purpose as the pursuit of prosperity for shareholders, stakeholders, and society. Taking a capacious view of the potential for corporate law to embrace a wide range of interests and to evolve over time, Williams advocates for giving conceptual weight to the corporation as an independent entity that can responsibly generate profits. Critically, in looking toward the future, Williams highlights that progress toward addressing global problems requires a shift in understanding corporations' role in solving the problems of "people and planet."

\section{BROADER THEORETICAL FOUNDATIONS FOR GROUNDING VIEWS OF CORPORATE PURPOSE AND PERSONHOOD}

Just as the chapters introduced in the preceding part provide a variety of approaches to social purpose beyond shareholder wealth maximization, the contributions in the next part look to multiple disciplines to inform their critique. The first two of this quartet use economic-informed theory, one based on logic and the other centered in macroeconomics. The final two trend to 
broader ideas of Dewey's pragmatism or concepts of attribution to bring new insights to our discussion.

Frank Partnoy's background in options trading and other areas of finance shows in his distinctive voice. Noting the debate over corporate purpose historically has implicated policy at its core, he pushes a different orientation that would use logic to address arguments about shareholder primacy. Partnoy challenges those who believe that shareholder wealth maximization leads to maximizing firm value to test that assertion via proof by counterexample, a foundational notion of logic. He leads the reader through a trio of counterexamples in which firms similar as to their core financial attributes differ as to their capital structure or residual or future claimants that would lead these similar firms to prioritize different opportunities.

A different part of the financial canon motivates Saule Omarova's view of corporate purpose. Her macro-systemic focus leads her to see the corporation as an inherently hybrid public-private entity that essentially outsources to private parties certain essential public powers and functions. The macro emphasis leads her to focus on maintaining a system-level balance between public and private and to view the relationship of government to the corporation as a franchise. She finds in the history of banks a classic example of purpose-driven businesses franchised by the government that could be recovered to good effect in the current debate.

Paul Miller's chapter notes how different answers will arise for questions of purpose and personhood if put as metaphysics, morality, social philosophy, politics, or law. The different implications that will follow from one or another is too often glossed over when the debate fixates on statements that corporations are people or should maximize shareholder wealth. Miller observes that for corporations to be meaningfully treated as persons, the law must enable attribution and liability, which is complicated by the difficulty in differentiating representative from personal acts taken by corporate actors. This leads to a broader discussion centered on better understanding the basis for vicarious liability in which corporate purpose turns out to be an effective mediating device for resolving the question of representative and personal acts.

High-profile disputes about corporate rights as to religious liberty and free speech have concealed important methodological advances that James Nelson tells us can guide the appropriate method of inquiry into these contentious issues. Drawing on the philosophical pragmatism of John Dewey in the 1920s, Nelson begins by steering the focus away from the nature of corporate existence and starting instead by asking whose interests are implicated in concrete situations. Methods that integrate moral deliberations and social science insights can be brought together to understand what is going on inside the corporation and better illuminate questions about corporate rights.

\section{CORPORATE PERSONALITY, POLITICS, AND RIGHTS}

Questions about personhood evolve fairly quickly into a question of corporate rights. Nelson's and Miller's chapters at the end of the prior part effectively show how purpose can mediate difficult claims as to corporate liability and rights. The chapters that follow provide several illustrations focusing on particular aspects of personhood and the rights that accrue to corporations.

Well-known attributes of the corporate form, such as limited liability and asset-partitioning, illustrate the immense value of legal personality in enabling the shifting of risk between 
insiders and outsiders in corporations and other entities. Courts and legislators sometimes reverse this attribute by veil piercing that holds insiders liable for entity obligations. Mariana Pargendler shines a light on a parallel legal phenomenon, long conflated with veil piercing, in which what is shifted is not liability for contracts but rather exposure to regulation. This parallel world, which she has creatively labeled "veil peeking", takes its turn at center stage in Pargendler's writings. She shows how partitioning the corporate entity as separate from its shareholders serves different considerations and functions in the regulatory versus contract settings. Through treatment across multiple areas of underlying law, she illustrates how asset partitioning and regulatory partitioning should not necessarily be subject to the same boundaries nor should all veil peeking be subject to uniform boundaries, and warns that courts cavalierly pushing the peeking into piercing precedent will only enhance the opportunity for regulatory arbitrage.

Much of the discussion about corporate personhood in corporate law reflects the law's acceptance of the entity's separateness to produce various social benefits. Kent Greenfield and Daniel Rubens focus their chapter on constitutional claims that depend on the rejection of corporate separateness so as to permit individual assertions of religious liberty. The authors note the longstanding acceptance of corporate separateness in various corporate law contexts (subject to piercing or peeking as discussed in Pargendler's chapter that have usually occurred via outsiders claiming that insiders misused the separateness to the outsiders' disadvantage). Greenfield and Rubens distinguish the corporation's need to litigate rights belonging to the corporation itself from those that are mere projections of the interests of its shareholders-no doubt a challenging task, but their core claim is that corporate law must inform the constitutional analysis. Their focus is the particular context in which a for-profit corporation seeks an exemption from antidiscrimination laws of general applicability based on the asserted religious or political beliefs of its owner.

The current Supreme Court's focus on individual rights to define the reach of corporate freedoms, grounded as it is in 19th-century ideas of the corporation as little more than an aggregation of individuals, might take caution from Sarah Haan's historical account of the effort to transmit American democratic traditions and norms to the corporate form across the 20th century. Early corporate theorists, as Haan develops the history, had a fairly well-elaborated and widely subscribed set of beliefs about the role of corporations in the democratic political system. In part this reflects a desire to restore the self-actualization that had characterized economic activity before industrialization, widely viewed as a necessary precondition for political self-government. By the end of the 1950s this was gone. The expansion of the shareholder holdings to produce broad economic citizenship never materialized. The Supreme Court's late 20th-century embrace of corporate democracy had been pared back from a substantive idea about dispersed economic ownership as citizenship to a narrow concept of proxy voting.

Miriam Baer's chapter on the criminal procedure rights of corporations adds an important dimension to understanding the personhood debate and the sometimes surprising way it can inform mainstream discussions and corporate practices. She starts by recounting the Supreme Court's Fourth Amendment jurisprudence on business entities and mapping the evolution of the collective entity doctrine, which denies corporations the Fifth Amendment privilege against self-incrimination. She shows how these doctrinal developments, with foundations over a century old, have contributed to a framework that aids regulators and prosecutors in their information-gathering and enforcement efforts - particularly in combination with the rise in corporate compliance programs. The practical desire to keep these compliance programs 
going, and relatively cheap enforcement of corporate crime and regulatory violations, has stunted the development of any sophisticated notions of corporate personhood in this space. Baer posits, however, that this state of affairs might be in jeopardy as the expansive reasoning of 21 st-century case law on corporate speech and religious liberty could pave the way for the Court's reconsideration of its criminal procedure precedents. She concludes by exploring the implications of this potential path for enforcement and the corporate compliance function.

\section{LESSONS FROM COMPARATIVE AND INTERNATIONAL STUDY AND POSSIBLE WAYS FORWARD}

We conclude with a series of chapters that use a comparative or international perspective to address possible ways forward. The first chapter in this part uses a wide lens in examining justifications for including stakeholders and societal interests in corporate purpose. The second chapter in this part centers on lessons from one country, India. The third combines a survey of national laws across multiple countries with data on how directors actually behave across multiple countries. Together, these last chapters contemplate tools for a broadened corporate purpose that has occupied the authors in this book.

Drawing on examples from a variety of jurisdictions, including the United Kingdom and the European Union, Martin Petrin probes theoretical and practical explanations for a broader corporate purpose. He identifies a number of reasons for supporting such a purpose, including the need to counterbalance corporate power, rule-making influence, negative externalities, and international arbitrage. Although Petrin observes that existing, traditional studies have not yet clearly proven that social performance increases business value as a general matter, he argues that countering climate change will ultimately be in the interests of nearly every business. Furthermore, he concludes that obstacles to moving away from shareholder primacy should not lead us to give up on stakeholders, and that recalibrating corporate law is an important complement to other regulatory reform.

Afra Afsharipour's chapter is a deep dive into efforts to broaden corporate purpose in one country-India. The multi-pronged response that she describes cuts across many of the approaches addressed earlier in the book - mandatory corporate social responsibility, a stakeholder-oriented articulation of director fiduciary duties, and increased sustainability disclosure for large firms. She reports mixed success: a significant increase in philanthropic giving but overall little dent being made in India's massive inequality, poverty, corruption, and pollution. In an economy with key firms dominated by controlling shareholders, it is not surprising that stakeholderist moves have made little headway. In fact, Afsharipour notes how CSR efforts have been used to curry political favor for the controllers, seeming to be little more than greenwashing. It is a warning that this movement may promise more than it can deliver.

Using broader data across multiple countries, Amir Licht combines data on the shareholder/ stakeholder orientation in a country's laws and then pairs those findings with a separate study of director decision-making based on a series of vignettes that generally test corporate purpose questions. The first study shows some difference between shareholder and stakeholder laws across countries, with common law countries leaning more toward shareholders, but the two legal systems are not "worlds apart." Even so, the responses of individual directors suggest that corporate leaders strive to implement strategies that are compatible with their own personal conceptions and values, notwithstanding the law. Implementing reform to change 
a legal system's shareholder/stakeholder orientation, he concludes, might therefore be an exercise in futility. What then would be the preferred way forward? Licht returns to Berle and Dodd from the early 1930s, as several of our authors have, and lays out the path he sees they share-a response for structural measures more than conduct rules.

Our goal in directing this book has been to invite the reader to a new consideration of corporate purpose and personhood. We believe it offers a perceptive route to better understand changes that are already apparent in the modern corporation across the world. We hope the twenty chapters presented here will provide you new ways to frame your thinking about corporate entities.

Elizabeth Pollman

Robert B. Thompson

August 2021 